\title{
Perkembangan Pemikiran Zaman Abbasiah Sebagal Akar Tafsir Ilmy Abad Modern
}

\author{
Wildana Wargadinata \\ Fakultas Humaniora dan Budaya Junusan Bahasa dan Sastra Arab \\ Universitas Islam Negeri (UIN) Malang \\ Jl. Gajayana 50 Malang 65144 Telp. 0341-551354, 558882
}

Faks. 0341-572533, 0341-558882

\begin{abstract}
The withdrawal process of Islamic science of al-Quran and al-Hadits born two currents thinking, firstly called by bilmanqul (irrational), all sciences which do not use mind to fetch its result, mind activity here to adjust the history from al-Quran and al-Hadits and comparing it with others also dig up the summary from the comparison. Secondly is bilmaqul (rational) thats all sciences which are taken by using mind, understanding its framework later fused back to be used to each others to be appropriate in fact. Here, mind occasion is strong in science scope and the result from the experiment depends on the appropriate mind.

In this case we can view the Abbasiyah era, which it is the golden phase through in Moslem history.Islamic sciences born and getting experience of maturity process. This case is pushed by social condition, culture, politic, and spiritual in that age which is inclined ideal in developing science. One of streams which born from the stream of Birroyis/Bilmaqul exegesis which grows in Abbasiyah era getting high development in the beginning of $20^{\text {th }}$ century is Ilmys exegesis in al-Quran. This stream grows speedy together in technology era and information which based on mind rationality.
\end{abstract}

Keywords: Abbasiyah era, Islamic sciences, Ilmys exegesis in al-Quran

\section{Pendahuluan}

Zaman Abbasiah adalah fase keemasan dalam perjalanan sejarah umat Islam. llmu-ilmu keislaman lahir dan mengalami proses kematangan pada zaman ini. Hal ini terdorong oleh kondisi sosial, budaya, politik dan spiritual pada masa itu yang cenderung ideal untuk perkembangan keilmuan. Kondisi politik mapan, dukungan para elit politik yang memang 
menghargai dan mencintai ilmu, bahkan memberi hadiah bagi para ulama dan cendekiawan yang berprestasi, ini merupakan salah satu faktor yang membawa fase Abbasiah menjadi fase keemasan bagi dunia keilmuan. Pesatnya perkembangan wilayah Islam membawa kepada pertemuan berbagai budaya lain, ditambah dengan gerakan penerjemahan, menambah maraknya lalu lintas ilmu di zaman itu.

Para ulama yang melihat banyaknya unsur asing yang masuk dalam dunia Islam, merasa bertanggung jawab untuk melestarikan bahasa alQuran dari kesalahan-kesalahan yang dibawa oleh orang non Arab. Dari sini timbullah bermacam-macam ilmu, yang tidak lain adalah untuk menjaga dan tetap mengaktualkan ajaran Islam agar dapat dipahami dan dijaga oleh umat Islam dari berbagai suku dan bangsa.

Zaman keemasan ini mulai mengalami masa surut yang sangat panjang, terutama pada masa antara abad $16 \mathrm{M}$ sampai akhir abad ke 18 . Masa ini disebut sebagai masa kegelapan dunia Islam. Meski secara keilmuan banyak para ulama yang tidak menerima pendapat ini, sehingga barangkali lebih tepat dinamakan fase jumud (kevakuman), karena tidak ada kreasi baru dalam dunia keilmuan. Kegiatan keilmuan fase itu hanya berkisar kepada menjelaskan buku-buku lama dan meringkasnya atau yang biasa disebut sebagai tradisi hawamish/hashiah dan tradisi ikhtishor. Tradisi seperti ini bukan tidak berarti, justru sebaliknya merupakan proses penyimpanan warisan intelektual yang paling efektif yang pernah dikenal manusia.

Salah satu warisan intelektual umat Islam yang mengalami perkembangan pesat di awal abad kedua puluh ini adalah Tafsir Ilmy alQuran. Aliran tafsir ini adalah salah satu aliran yang lahir dari aliran tafsir birroyi yang tumbuh pada zaman Abbasiah. Segi keilmiahannya berkembang pesat bersama dengan pesatnya era tehnologi dan informasi yang bersendi kepada rasionalitas akal.

Tulisan ini mengurai lebih lebar lagi tentang tafsir ilmy modern dengan menarik kepada akar mulanya di zaman Abbasiah. 


\section{Kondisi Sosial Politik Zaman Abbasiah}

Masa dinasti Abbasiah adalah salah satu episode perjalanan panjang sejarah umat Islam. Dimulai dengan seruan Allah kepada Muhammad untuk menyampaikan misi kenabian kepada umatnya, menyeru kepada kebaikan dan meluruskan kebatilan. Perjalanan pemerintahan masyarakat baru Islam ini kemudian dilanjutkan oleh Khulafah Rasyidah, empat orang sahabat yang paling dekat dengan Rasulullah. Fase ini berakhir dengan kematian khalifah yang keempat Ali ra. Dari sini tampuk pemerintahan pindah ke tangan Muawiyah bin Abu sufyan tahun $40 \mathrm{H}$. Fase ini dikenal dengan zaman dinasti Umawiyah.

Berdirinya dinasti Umawiyah oleh Dr. Muslim Abdullah Alu Jafar disebut sebagai periode kemenangan satu golongan atas golongan yang lain (periode partai). (Muslim Abdullah Alu Jafar, 1984: 20). Butir perpecahan umat Islam dimulai dengan terbunuhnya Usman bin Affan. Perpecahan terus berlangsung dan tidak dapat diredakan meski dengan terbunuhnya Ali r.a dan berdirinya dinasti Umawiyah. Beberapakelompok terus melakukan pemberontakan, akan tetapi semuanya kemudian dipadamkan, lalu muncul pergolakan yang lain, datang dan pergi sesuai dengan kondisi dan keadaan.

Pada masa-masa terakhir dinasti Umawiyah, perpecahan mulai terangkat lagi ke permukaan sedemikian parahnya, akhirnya membawa keruntuhan dinasti Umawiyah. Keruntuhan dinasti Umawiyah diantaranya disebabkan oleh sikap Arabisme yang mendominasi pemerintahan dinasti Umawiyah. Hal ini menyebabkan mayoritas umat Islam tersiksa lahir batin, baik Arab maupun yang non Arab, karena mereka mengerti bahwa Islam bukan hanya untuk orang Arab saja, akan tetapi sebagai rahmat bagi seluruh umat manusia. Fanatisme tersebut sampai melahirkan peraturan pengambilan jizyah bagi orang Islam yangnon $A$ rab yang terus berlangsung hingga pemerintahan Umar bin Abdul Aziz.

Umat Islam yang tidak puas dengan sikap fanatisme tersebut mulai bergabung dengan kelompok-kelompok yang melakukan pemberontakan seperti Abdullah bin Zubair, kemudian bergabung dengan Mukhtar asSaqofy dan terakhir bergabung dengan kelompok dakwah bani Abbasiah. 
Orang-orang bani Abbasiah dapat memanfaatkan mereka dengan baik. Para Ahli sejarah berpendapat, bahwa yang mendorong bani Abbasiah untuk memimpin umat Islam memperbaiki kondisi Umat Islam yang telah dirusak oleh bani Umawiyah adalah pemberitahuan dari Nabi saw. kepada Abbas bin Abdul Muttolib, bahwa kekhilafahan akan dipegang oleh anak cucunya. (Abu Jafar Muhammad bin Jarir at-Tobary, 1966: 421) Dari sini mereka terus mengharap kejadian tersebut menjadi kenyataan.

Banyak hal yang mengantarkan Bani Abbasiah untuk meraih tampuk pemerintahan diantaranya:

1. Mengambil pelajaran dari kesalahan musuh yang menggunakan politik sebagai pemeran utama kampanye mereka, sementara orangorang Abbasiah banyak menggunakan jalur agama.

2. Para khalifah Umawiyah banyak melakukan kesalahan vital dengan melakukan pesta-pesta dan perbuatan maksiat yang melengahkan mereka dari pemerintahan. Meski mereka sudah merasakan adanya gerakan bawah tanah yang bermaksud menggulingkan pemerintahan mereka.

3. Dakwah Abbasiah menggunakan slogan-slogan:

a Persamaan antar sesama muslim dalam hak dan kewajiban tanpa membedakan suku dan bangsa.

b Perbaikan kondisi sosial keagamaan bagi kaum muslimin.

c Mencintai Ahli Bait yaitu keluarga Rasulullah saw.

Gerakan dakwah Abbasiah terus berjalan secara rahasia sampai pada tahun $132 \mathrm{H}$, Tentara Abbasiah yang dipimpin oleh Abdullah bin Ali bertemu degan tentara Umawiyah yang dipimpin oleh khalifah Marwan bin Muhammad, yang dimenangkan oleh Bani Abbasiah dengan terbunuhnya khalifah terakhir dari bani Umawiyah. Bani Abbasiah memimpin pemerintahan Islam selama 5 abad seperempat sampai tahun $656 \mathrm{H}$, ketika pemerintahan mereka digulingkan oleh tentara Tatar Mongol. 
Beberapa ciri kondisi sosial zaman dinasti Abbasiah yang berbeda dengan fase-fase sebelumnya dalam sejarah umat Islam adalah sebagai berikut: (Ahmad Amin, 1935: 162).

1- Gerakan Abbasiah berdiri di atas prinsip persamaan antara mawali orang muslim non arab dengan orang.Arab dalam setiap hak dan kewajiban. Hal ini memberi kesempatan luas pada orang Islam non Arab untuk melakukan kegiatan ilmiah, politik dan kemasyarakatan di komunitas Islam. Dampaknya sangat menguntungkan keilmuan Islam, karena budaya-budaya asli yang mereka bawa, seperti Persia, India, Romawi, Yunani akhirnya dipergunakan untuk berkhidmah kepada Islam.

2- Menonjolnya unsur agama pada pemerintahan Abbasiah. Hal ini tampak dari dukungan khalifah terhadap kemajuan ilmu, penghormatan kepada ulama dengan mendekati dan menerima nasehat-nasehat mereka.

3- Luasnya wilayah Abbasiah melahirkan sistem pemerintahan desentralisasi. Akibatnya selain ibukota Baghdad, telah lahir pusatpusat kebudayaan dan keilmúan seperti Syam, Mesir, Musol, Khurasan, Bukhoro dan lain-lain.

4- Berkembangnya fungsi masjid dari halaqoh-halaqoh agama menjadi universitas-universitas segala macam ilmu bahkan ilmu yang tidak ada hubungannya dengan agama.

5. Ciri lain yang menonjol adalah semaraknya gerakan tarjamah dan pencetakan buku-buku ilmiah.

\section{Perkembangan Keilmuan Pada Masa Dinasti Abbasiah}

Al-Quran al-Karim adalah sumber segala keilmuan umat Islam, dan Hadits nabi adalah bagaikan batu asas bagi berdirinya madrasah-madrasah keilmiahan Islam. Semua ilmu dan cabang-cabangnya tidak ada yang terlepas dari kedua sumber tersebut, demikian juga dengan kegiatan pemikiran mereka. 
Proses pengambilan ilmu dari al-Quran dan hadits melahirkan dua aliran pemikiran. Pertama apa yang disebut sebagai bilmanqul (non rasio), segala ilmu yang tidak menggunakan akal untuk mengambil hasilnya, kegiatan akal di sini hanyak mencocokkan sumber-sumber riwayat dari alQuran dan al-Haditts serta mengkiaskannya dengan hal lain dan mengambil kesimpulan dari kias tersebut. Kedua adalah bilmaqul (rasional), yaitu segala ilmu yang diperoleh dengan menggunakan akal, memahami kerangka-kerangkanya kemudian dirakit kembali untuk dipakai pada hal lain yang sesuai dengan kenyataan. Di sini peran akal sangat besar dalam lingkup ilmu sehingga hasil dari sebuah percobaan tergantung kepada kecocokannya dengan akal.

llmu-ilmu bilmanqul meliputi ilmu-ilmu syariat, ilmu-ilmu bahasa, sejarah, ilmu negara-negara yang sekarang disebut geografi. Sedang ilmuilmu bilmagul adalah Mantiq, Filsafat, Aqidah, Matematika, Kedokteran, Fisika, Kimia. Zaman Abbasiah adalah wilayah yang subur untuk perkembangan ilmu-ilmu tersebut di atas. Fase Abbasiah hampir melahirkan ilmuwan-ilmuwan untuk setiap bidang dan melahirkan bukubukunya. Sebagai contoh pada bidang tafsir dan hadits adalah Abdul Malik bin Abdul Aziz bin Juraid (wafat $150 \mathrm{H}$ ) yang mengarang tafsir dan mengumpulkan hadits, Abdurrahman bin Amru Al-auzai (156 H), Imam Bukhori $(256 \mathrm{H})$, Imam Muslim $(263 \mathrm{H})$, yang menjadi teladan bagi para penerusnya dan petunjuk bagi umat Islam. Kemudian lahir Ulumul Hadits, ilmu-ilmu al-Quran, Tafsir dll.

Sedang dalam bidang fiqih, setelah meluasnya wilayah Islam, umat Islam membutuhkan hukum-hukum baru untuk menjawab persoalanpersoalan di berbagai daerah Islam. Ilmu fiqih lahir secara berdiri sendiri pada masa Abu Hanifah Numan bin Tsabit $(150 \mathrm{H})$ yang menjadikan ijtihad, qiyas, ijma sebagai sumbernya. Kemudian muncul Imam Malik bin Anas (wafat tahun $179 \mathrm{H}$ ), Imam Syafii Muhammad bin Idris (wafat tahun $204 \mathrm{H}$ ), dan Imam Ahmad bin Muhammad bin Hanbal (wafat tahun 244 $\mathrm{H})$. Mereka inilah yang dikenal sebagai Imam madzhab empat yang masih diikuti umat Islam sampai sekarang.

Masuknya orang-orang non Arab ke dunia Islam menyebabkan banyaknya kesalahan mengucapkan kata-kata Arab, karena mereka tidak 
mengerti irab. Maka untuk menjaga dan melindungi bahasa Arab dari kesalahan, lahirlah Ilmu Nahwu, yang mencapai kesempurnaan di tangan Sibawaih dalam bukunya "Al-Kitab". Sebelum Sibawaih ilmu dipelopori oleh Abul Aswad Ad-Duali (wafat tahun $69 \mathrm{H}$ ) dan tokoh nahwu pertama yang masuk zaman Abbasiah adalah Isa bin Amru As-Saqofi (wafat tahun $149 \mathrm{H}$ ). Dengan lahirnya Nahwu, mulailah ilmu-ilmu bahasa lahir yaitu: Balaghah, Adab, Fiqih Lughah, Sharaf dan lain-lain.

Kemudian perhatian besar umat Islam terhadap Nabi Saw., melahirkan buku sejarah dan biografi rasul yang dikenal dengan sirah nabi. Diriwayatkan bahwa Wahab bin Munabbih (wafat tahun $110 \mathrm{H}$ ) menulis buku tentang peperangan rasulullah. Demikian juga dengan Musa bin Uqbah (wafat tahun 141 H). (Ahmad Amin, 1935: 158). Demikian pula yang terjadi dengan ilmu-ilmu yang lain, berkembang pesat pada zaman Abbasiah.

\section{Tafsir Bilmat'sur dan Tafsir Birro'yi}

Perkembangan tafsir pada zaman Abbasiah selanjutnya melahirkan dua aliran penafsiran, yaitu pertama, tafsir bilmatsur yaitu penafsiran yang berdasarkan kepada penjelasan-penjelasan yang diperoleh dari ayat-ayat al-Quran, hadis-hadis nabi atau pendapat para sahabat. (Quraish Shihab, 1994: 121).

Tafsir ini dalam perkembangan awalnya, berjalan sangat pesat terutama karena mendapat penghargaan dari masyarakat dan diterima dengan puas. Sebaliknya tafsir birroyi, yaitu tafsir yang memberi kesempatan besar kepada akal untuk berijtihad setelah seorang mufassir itu mengerti bahasa arab, balaghah-nya dan mengerti idiom-idiomnya dengan bantuan syiir-syiir abad jahiliah, mengetahui asbabun nuzul, nasikh mansukh dan segala ilmu yang dibutuhkan oleh seorang mufassir (Husain Dzahabi: 87). Aliran ini pada masa awalnya mendapat tantangan yang cukup keras dari umat Islam bahkan ada sebagian kaum yang mengharamkan. Hal tersebut menyebabkan pengkultusan tafsir bilmatsur, terbukti Madrasah Abdullah bin Abbas berubah menjadi aliran tafsir bilmatsur, padahal aliran ini awalnya adalah aliran tafsir birroyi. 
Beberapa tafsir yang merupakan tafsir bilmatsur menurut Husain Dzahabi (1962: 86) adalah sebagai berikut :

1. Jamiul Bayan fi tafsiril Quran : Ibnu Jarir At-Thobari

2. Bahrul Ulum : Abu Laits Samarqandi

3. Maalimu At-Tanzil : Abu Muhammad Husain Baghawi

4. Tafsir Quran Adhim : Ibnu Katsir

5. Ad-Durrul Mansur : Jalaluddin As-Suyuti

Sedangkan tafsir birroyi yang menurut Dzahabi (1962: 99) yang boleh dipakai adalah :

1. Mafatihul Ghoib

2. Anwaru At-tanzil

3. Madariku At-Tanzil

4. Bahrul Muhit

6. Ruhul Maani
: Fakhrurrozi

: Baidhowi

: Nasafi

: Abu Hayyan

: Alusy

\section{Akar Tafsir Ilmy Pada Masa Dinasti Abbasiah}

Aliran keilmuan Islam yaitu aliran akal dan aliran salaf, melahirkan dua aliran penafsiran dalam tafsir, yaitu tafsir bilmatsur dan tafsir birroyi. Dari tafsir birroyi ini kemudian melahirkan tafsir ilmy/kauny (ilmiah). Di antara tokoh yang paling awal dan paling getol menyebarkan tafsir ilmy adalah Imam abu Hamid al-Ghazali yang meninggal tahun $505 \mathrm{H}$, (Abdul Majid Abdussalam Al-Muhtasab, 1982: 247) seorang tokoh sufi yang melihat kata-kata dalam al-Quran itu memiliki makna lahîr dan makna batin sebagaimana yang disitir dalam hadits. Dalam bukunya Ihya Ulumuddin, Imam Ghazali mengemukakan pendapatnya tentang tafsir ilmy dengan menukil beberapa pendapat ulama: Abu Darda mengatakan; Seseorang itu tidak akan mengerti dengan baik sebelum menjadikan itu memiliki berbagai pandangan. Sebagian ulama mengatakan; Setiap ayat itu memiliki 60.000 pemahanan, dan sisanya masih lebih banyak lagi. Ibnu 
Masud ra. berkata; Barangsiapa ingin mengetahui ilmu-ilmu orang dahulu dan orang sekarang, silahkan merenungi al-Quran. Dan untuk melakukan itu menurut Imam al-Ghazali tidak bisa dicapai hanya dengan pemahaman lahir.(Al-Ghazali, 1968: 260).

Dalam bukunya Jawahirul Quran, yang dikarang setelah Ihya, Imam Ghazali menerangkan lebih banyak lagi tentang pernyataan yang telah beliau lontarkan di bukunya lhya. Beliau menulis bab keempat, tentang bagaimana ilmu-ilmu agama itu berkembang menjadi bercabang-cabang ilmu dan hubungannya dengan al-Quran. Imam Ghazali membagi ilmuilmu al-Quran menjadi dua:

1. Ilmu Kulit yang terdiri dari; ilmu Bahasa, ilmu Nahwu, ilmu Qiraat, ilmu Tajwid, ilmu Tafsir lahir.

2. Ilmu Isi yang meliputi; Pengetahuan tentang kisah-kisah dalam alQuran termasuk kisah para nabi, ilmu kalam, ilmu fiqih, ilmu ushul fiqih, mengetahui Allah dan hari akhirat, pengetahuan tentang jalan yang lurus. Ini semua adalah cakupan ilmu yang lahir dari alQuran.

Kemudian Imam Ghazali membuat bab kelima tentang bagaimana ilmu-ilmu yang lain lahir dari al-Quran. Maka disebutlah ilmu kedokteran, ilmu perbintangan, alam semesta, kerangka badan hewan, ilmu tubuh dan lain-lain. (Al-Ghazali, 1964: 21).

Kalau Imam Ghozali telah meletakkan teori-teorsi penafsiran ilmiah terhadap al-Quran, maka Imam Fakhrurrozi-lah yang mempraktekkannya dalam sebuah tafsir quran yang dikenal dengan Tafsir Kabir. Fakhrurrozi memasukkan dalam tafsirnya segala hal yang tumbuh dan berkembang di masyakat muslim dari pemikiran, budaya dan teknologi, sehingga beberapa ulama mengomentari tentang tafsir ini dengan: Fakhrurrozi telah mengatakan segala sesuatu di dalam tafsirnya. (Abdul Majid Abdussalam Al-Muhtasab, 1982: 251). 


\section{Tafsir Ilmy Di Abad Modern}

Masa antara abad ke $16 \mathrm{M}$ sampai akhir abad $18 \mathrm{M}$ merupakan masa kegelapan dunia Islam. Kondisi fisik dan keilmuan sangat memprihatinkan. Sebaliknya roda kemajuan bangsa Eropa melaju sedemikian cepatnya. Kesadaran umat Islam mulai muncul dengan mengirim beberapa utusan untuk menimba teknologi dari barat dan bukan pemikiranya. Akan tetapi beberapa utusan Mesir ke Eropa juga mengadopsi pemikiran barat yang menimbulkan pertentangan yang hebat dari para ulama.

Pada pertengahan abad ke-19 kondisi umat Islam semakin buruk, dengan datangnya bangsa Eropa yang menjajah dan mengirim para misionaris. Mereka bahkan menyebarkan doktrin bahwa penyebab utama kemunduran dunai Islam adalah al-Qur an. Mereka juga-berusaha menjatuhkan pusat pemerintahan Islam di Istambul.

Pada saat itulah beberapa ulama mulai merenungi kembali al-Quran dan melihat betapa al-Quran mengandung prinsip-prinsip dasar keilmuan dan tehnologi. Aliran tafsir ilmy ini semakin populer pada awal abad duapuluh, dipopulerkan oleh Syaih Muhammad Abduh yang sekaligus dikenal sebagai tokoh pembaharu abad duapuluh. Aliran M. Abduh yang sangat rasional ini tidak terlepas dari aliran pemikiran rasional yang memang telah tumbuh pesat pada masa dinasti Abbasiah. Pemikiran $M$. Abduh kemudian juga dituangkan dalam tafsir al-Quran dengan corak ilmiah yang kemudian dilengkapi oleh Syaikh M. Rasyid Ridha.

Beberapa buku penafsiran yang bercorak ilmiah pun berkembang demikian pesatnya, diantara yang terkenal adalah Kasyful Asrar Nuroniah yang berkenaan dengan benda-benda langit dan bumi, hewan, tumbuhtumbuhan dan barang-barang tambang mulia. Karangan Muhammad bin Ahmad Iskandarany yang dicetak oleh percetakan Wahbiah tahun 1297H.(Husain Dzahabi, 1962: 163). Dalam tafsirnya, Mahasinu Tawil, Jamaluddin al-Qosimy -seorang pengagum M. Abduh- menggunakan corak ilmiah pada penafsirannya. Pada muqoddimah juz pertama tafsir tersebut, dia membuat satu judul yang membahas pelik-pelik masalah ilmu falak yang ada dalam al-Quran. Syaikh Tontowi Jauhari mengarang tafsir ilmy 
yang diberi judul "Jawahir fi Tafsiril Quran" terdiri dari 25 juz. Dalam pembukaannya beliau mengatakan: Amma Badu, Sesungguhnya aku telah dilahirkan untuk mencintai keajaiban-keajaiban alam, mengagumi keindahan alam, rindu untuk melihat-lihat keindahan di langit dan yang di bumi, petunuk-petunjuk yang nyata, serta keanehan menakjubkan (Jauhari, 1300: 2). Tokoh-tokoh semacam Abdul Hamid Badish, Mustofa Shodiq Rafii, Abdur Rozaq Naufal juga ikut memperkaya literatur-literatur tafsir ilmy al quran.

\section{Kesimpulan}

Meski tafsir ilmy tidak diakui oleh berapa ulama seperti Rasyid Ridha, Mahmud Syaltut, Mustofa Marogi, akan tetapi penafsiran ini telah ikut mengurai sisi indah dari al-Quran, yang kata seorang ulama tafsir bagaikan intan yang berkilau dari berbagai sisi.-Tiap sisinya memiliki kilauan yang lain dari sisi yang lain, semuanya indah. Pada intinya perwujudan dari keindahan sang Pencipta. 


\section{DAFTAR PUSTAKA}

Ahmad, Amin. 1935. Dhuha al-Islam. Kairo:Percetakan Lajnah Talif Wa Tarjamah.

. 1935. Fajrul Islam. Kairo: Percetakan Lajnah Talif Wa Tarjamah,.

Al-Ghozali, Abu Hamid. 1968. Ihya Ulumuddin Kairo: Maktabah Halaby. . 1964. Jawahirul Quran. Kairo: Maktabah Jundy.

Al-Muhtasab, Abdul Majid Abdussalam. 1982. Ittijahat Tafsir fil Asri alRohin, Dar Bayariq. Beirut: Cetakan ke III.

At-Tobary, Abu Jafar Muhammad bin Jarir. 1966. Tarikh Tobary. Kairo: Darul Maarif.

Dzahabi, Husain. 1962. Tafsir wal Mufassirum. Kairo: Dar Kutub al-Hadisah. Jafar, Muslim Abdullah Alu. 1984. Asar al-Tathowuur al-Fikri fi al-Tafsir fi al-Asri al-Abbasy. Beirut: Muassasah Risalah.

Jauhari, Tontowi. $1300 \mathrm{H}$. Al-Jawahir fi Tasiril Quran Karim. Kairo: Percetakan Mustofa Halabi.

Shihab, Quraish. 1994. Studi Kritis Tafsir Al-Manar, Bandung: Pustaka Hidayah. 